\title{
Inhibitory effects of crude extracts from some edible Thai plants against replication of hepatitis $B$ virus and human liver cancer cells
}

\author{
Wanwisa Waiyaput', Sunchai Payungporn², Jiraphorn Issara-Amphorn' \\ and Nattanan T-Thienprasert Panjaworayan ${ }^{1 *}$
}

\begin{abstract}
Background: Edible plants such as Cratoxylum formosum (Jack) Dyer, Curcumin longa Lin, Momordica charantia Lin and Moringa oleifera Lam have long been believed in Thai culture to relieve ulcers and the symptoms of liver disease. However, little is known about their anti-liver cancer properties and antiviral activity against hepatitis B virus (HBV). The aim of this study was to investigate the anti-liver cancer and anti-HBV activities of crude extracts from these edible plants on human liver cancer cells.

Methods: Plant samples were prepared and extracted using buffer and hydro-alcoholic solvents. The MTT assay was performed to investigate the effects of the plant extracts on the cell viability of HepG2 cells. The inhibitory effect on replication of HBV was analysed by determining the level of HBV covalently closed circular DNA (cccDNA) in transiently transfected HepG2 cells with the DNA expression plasmid of the HBV genome using a quantitative real-time PCR.

Results: Buffer and hydroalcoholic extracts from C. formosum (leaf) reduced cell viability of HepG2 cells and they also inhibited HBV cccDNA. Crude extracts from C. longa (bulb) in both solvents did not have any cytotoxic effects on the HepG2 cells, but they significantly decreased the level of HBV cccDNA. Buffer extracts from the leaves of $M$. charantia and the fruits of $M$. oleifera showed to have anti-HBV activity and also a mild cytotoxicity effect on the HepG2 cells. In addition, leaves of M. Oleifera extracted by hydroalcoholic solvent drastically decreased the level of cccDNA in transiently transfected HepG2 cells.
\end{abstract}

Conclusion: Some crude extracts of edible plants contain compounds that demonstrate anti-liver cancer and anti-HBV activities.

Keywords: Antiviral activity, Anti-liver cancer, HBV cccDNA, Hepatitis B virus, Edible Thai plants

\section{Background}

Hepatitis B virus (HBV) infection is a major global health problem that can cause liver cirrhosis and liver cancer. Although the HBV vaccination can effectively prevent new infections, current HBV antiviral drugs are reported to have adverse effects on patients or promote the development of drug-resistance [1]. Therefore, novel antiviral drugs and alternative treatments are urgently needed for millions of people that are chronically

\footnotetext{
* Correspondence: fscinnp@ku.ac.th

${ }^{1}$ Department of Biochemistry, Faculty of Science, Kasetsart University, Bangkok, Thailand

Full list of author information is available at the end of the article
}

infected with HBV. Currently, much attention has been focused on dietary factors that reduce the risk of cancers [2]. Natural products or phytonutrients appear to be potent therapeutics for viral diseases and cancers [3-5].

A number of edible plants in Thailand have been traditionally used to cure illness. For example, the roots and leaves of Cratoxylum formosum (Jack) Dyer can be used in a diuretic based diet that may relieve symptoms of liver cirrhosis. Bulbs of Curcumin longa Lin has been consumed to treat stomach ulcers and is believed to help prevent liver cancer [6]. The pods and leaves of Moringa oleifera Lam have been taken orally to fight cancers and control inflammation. The fruits and leaves of 
Momoridica charantin Linn have been consumed to cure symptoms of liver diseases [7]. In addition, several studies have confirmed the medical properties of these edible plants. For example, curcumin extracted from $C$. longa has been reported to have anti-inflammatory and antioxidant properties and shows antiviral activity for HBV and hepatitis $C$ virus [8-10]. Oil and emulsion extractions from leaves from $C$. formosum have been reported to have high antioxidant activity [11]. 70\% methanol extraction of bark from $C$. formosum has been demonstrated to have diuretic effects [12]. Fruit extracts of $M$. charantia have displayed anticancer and antiviral activities against HIV and herpes virus [13,14]. Extracts of $M$. oleifera has shown to inhibit the replication of herpes virus and Epstein-Barr virus [15,16]. Nonetheless, the anti-liver cancer and anti-HBV properties of $C$. formosum, M. charantia and M. oleifera have not yet been investigated.

This study therefore investigated inhibitory effects of crude extracts from C. formosum, M. charantia and $M$. oleifera on the viability of human liver cancer cells (HepG2) and their antiviral activity against the replication of the template of $\mathrm{HBV}$ transcription (Covalently closed circular DNA or cccDNA). C. longa hot water extract was included in this study as the positive control for the anti-HBV property.

\section{Methods}

\section{Preparation of plant materials}

Four edible Thai plants, C. longa, C. formosum, M. charantia and $M$. oleifera were purchased from a local market in Bangkok. The plants were dried under shade for 3 weeks and grounded into powder and stored at $4^{\circ} \mathrm{C}$ until further use. The powder was then extracted by two different solvent systems, the first being a $80 \%$ hydroalcoholic solvent (80\% ethanol and $20 \%$ distilled water) and the second, a $50 \mathrm{mM}$ Tris- $\mathrm{HCl}$ buffer ( $\mathrm{pH} 7.5)$. For hydroalcoholic extraction, samples were shaken in $80 \%$ hydroalcoholic solvent for $16 \mathrm{~h}$ at room temperature. Then, the solutions were filtered, and then the filtrate was re-suspended and shaken in ethanol for $48 \mathrm{~h}$. All extracts were pooled, re-filtered and concentrated using a rotary evaporator and then lyophilized. Prior to testing, the lyophilized extracts were dissolved in distilled water to produce $1 \mathrm{~g} / \mathrm{L}$ of plant extracts. The extract yield (\%, $\mathrm{w} / \mathrm{w})$ was determined from all hydroalcoholic extracts by using the formula:

\section{Yield(\% )}

(The weight of extract after lyophilisation of solvent $\times 100$ ) The weight of the plant powder

(Additional file 1: Table S1).
For buffer extraction, the samples were incubated in buffer for $48 \mathrm{~h}$ at $4^{\circ} \mathrm{C}$ in the dark, filtered, and then centrifuged at high speed for $30 \mathrm{~min}$ at $4^{\circ} \mathrm{C}$. The supernatant of each sample was collected and dialysed in Tris- $\mathrm{HCl}$ for $48 \mathrm{~h}$, then total protein was determined using the Bradford assay, using BSA as a protein standard. The total protein of each buffer extract is presented in Additional file 1: Table S1.

\section{Cell culture and transfection}

Both COS-7 and HepG2 (ATCC, gifts from The Centre of Excellence Clinical Virology and Molecular Biology Research, Chulalongkorn University) were cultured in DMEM (Gibco, Invitrogen) and supplemented with $10 \%(\mathrm{v} / \mathrm{v})$ heat inactivated fetal bovine serum (Gibco, Invitrogen) and $1 \%(\mathrm{v} / \mathrm{v})$ antimicotic antibiotic (Gibco, Invitrogen). All cell lines were cultured in $75 \mathrm{~cm}^{3}$ sterile tissue culture flasks at $37^{\circ} \mathrm{C}$ under a $5 \% \mathrm{CO}_{2}$ atmosphere. For quantitative real time-PCR, HepG2 cells were seeded on 24-well plates with approximately $1 \times 10^{5}$ cells in each well. Seeded cells were treated with either $30 \mu \mathrm{g} / \mathrm{mL}$ of hydroalcoholic crude extracts or buffer extracts containing $0.3 \mu \mathrm{g}$ total protein and then transfected with $1 \mu \mathrm{g}$ of the DNA expression plasmid of HBV genome (pHBV48, a gift from $\mathrm{M}-\mathrm{H}$ Lin, National Taiwan University) [17] and using the Lipofectamine $^{\mathrm{TM}} 2000$ in triplicate. This plasmid has been reported to express full-length HBV and is able to produce HBV particles in cells [17]. For the positive control, cells were transfected with $1 \mu \mathrm{g}$ of pHBV 48 without addition of crude extracts. The ratio between Lipofectamine $^{\mathrm{TM}} 2000(\mu \mathrm{L})$ and DNA $(\mu \mathrm{g})$ was 3:1. After 5 days of incubation, cells were subjects to DNA extraction and real-time analysis.

\section{Cell viability assay (MTT assay)}

COS-7 and HepG2 cells were seeded on 96-well plates with a cell density of approximately $1.5 \mathrm{x} 10^{3}$ cells per $150 \mu \mathrm{L}$ of media in each well. After $24 \mathrm{~h}$ of incubation, cells were added with 0 (solvent only), 50, 150 and $300 \mu \mathrm{g} / \mathrm{mL}$ of hydroalcoholic extracts. For buffer extracts, cells were incubated with 0 (buffer only), $0.5,1,1.5$ and $2 \mu \mathrm{g}$ of total protein extracts from each plant. A cell-free control was also included to exclude any false positive results from the assay [18]. Each sample was performed in quadruplicate and cells were incubated for 3, 5 and 7 days. After incubation, the culture medium was removed from each well by aspiration and $4 \mu \mathrm{g}$ of MTT (Invitrogen) was added into each well. After $3 \mathrm{~h}$ of incubation, DMSO (Amresco) was added to dissolve the purple formazan of MTT. The absorbance was then measured by a microplate reader at a wavelength of 
$570 \mathrm{~nm}$. The cell viability (\%) was calculated using the formula: (df $)=n_{1}+n_{2}-2$. A p-value was determined from the probability table [20]. A $\mathrm{P}$ value $<0.05$ indicated the presence of a statistically significant difference.

(Absorbance of test compound - Absorbance of cell free control)

$\overline{\text { (Absorbance of cell without treatment - Absorbance of cell free control) }}$ $\times 100$

\section{Quantitative real time- PCR analysis of HBV cccDNA}

Total DNAs were isolated from each well using a genomic DNA Extraction mini kit (RBC Bioscience) according to the manufacturer's instruction. HBV cccDNA was amplified and quantified by real-time PCR assay using specific primers: HBV_CCC_F1 (5'- actcttggactccag caatg-3') and HBV_CCC_R1 (5'-ctttatacgggtcaatgtcca-3') with SYBR-green. These pair of primers was designed to match the region corresponding to the gap and incomplete region in the partially double- stranded HBV DNA. Therefore, they specifically amplify DNA fragments from HBV cccDNA but not from genomic DNA [19]. Negative control (no DNA template) was included to determine contamination whereas the positive control (transfected cells with $1 \mu \mathrm{g}$ of pHBV48) was performed to yield quantitative information. Each sample was performed in triplicate. A result was indicated in terms of a relative quantitation by the comparative threshold (delta-delta Ct) method, $\left(2^{-\Delta \Delta C t}\right)$. In this study, the reference gene was beta-globin. The target gene was the cccDNA of transfected HBV and the calibrator was cells transfected with only the HBV plasmid.

\section{Statistical analysis}

Student's t-test [20] was used for comparing data between control cells (COS-7) and human liver cancer (HepG2) cells in the viability assay. It also used to determine significant differences between the positive control (transfected cells with pHBV48 without addition of crude extracts) and treated cells with crude extracts in the real-time analysis. A statistic $t$ was calculated using the formula:

$$
\begin{aligned}
\mathrm{t} & =\frac{\left(\overline{\mathrm{X}}_{1}-\overline{\mathrm{X}}_{2}\right)}{\mathrm{S}_{\mathrm{p} \times} \sqrt{\frac{1}{\mathrm{n}_{1}}+\frac{1}{\mathrm{n}_{2}}}} \text { when } \\
\mathrm{S}_{\mathrm{p}}^{2} & =\frac{\left[\left(\mathrm{n}_{1}-1\right) \mathrm{S}_{1}^{2}+\left(\mathrm{n}_{2}-1\right) S_{2}^{2}\right]}{\mathrm{n}_{1}+\mathrm{n}_{2}-2}
\end{aligned}
$$

$\overline{\mathrm{X}}$ and $\overline{\mathrm{X}}_{2}$ are means of \% cell viability of COS-7 cells and HepG2 cells respectively; $S_{p}$ is the sample standard deviation (uncertainty value); $S_{1}^{2}$ is COS-7 sample variance; $S_{2}^{2}$ is HepG2 sample variance; $n_{1}$ is number of COS-7 sample and $n_{2}$ is number of HepG2 sample. The $t$ distribution was used with the degree of freedom

\section{Results and discussion}

Effects of crude extracts on the viability of HepG2 cells

To examine whether extracts from tested edible Thai plants could inhibit the viability of liver cancer cells, an optimisation of the MTT assay was performed on the non-cancerous cell (COS-7) for evaluating: (i) the appropriate concentration of crude extract needed such that there was no cytotoxic effects on the normal cells, (ii) the amount of MTT compound needed and (iii) the duration of effects. We used hot water extracts of $C$. longa as our analytical control because its cytotoxicity and anti-HBV activity were previously reported on the livercancer cells [9]. Subsequently, COS-7 cells were treated with various concentrations of $C$. longa hot water extract $(100-900 \mu \mathrm{g} / \mathrm{mL})$ and different amounts of MTT $(2-8 \mu \mathrm{g})$ and then the MTT assay was performed after 3, 5 and 7 days post-incubation. A high variation of cell viability was observed when cells were treated with $8 \mu \mathrm{g}$ of MTT while using $2 \mu \mathrm{g}$ of MTT produced an unclear pattern of dose dependent effects at any time setting (Figure 1). At day 5, the cytotoxicity effect of C. longa extract was moderately elevated in a dose dependent manner with $4 \mu \mathrm{g}$ of MTT and the concentrations of extracts at higher than $300 \mu \mathrm{g} / \mathrm{mL}$ drastically affected cell viability (less than $65 \%$ of cell viability, Figure 1B). At day 7, the inhibitory effect was absent and most of the cells were found to be unhealthy when viewed under a microscope leading to relatively high variation of data (Figure 1C). Therefore, the appropriate amount of MTT was $4 \mu \mathrm{g}$ and the optimal concentration of C. longa hot water extract that had no effect on the normal cells was less than $300 \mu \mathrm{g} / \mathrm{mL}$. The best inhibitory effect was observed at day 5 . These optimal conditions were used when analysing the inhibitory effects of all crude extracts on COS-7 and HepG2 cells. The data analysed at day 5 were shown as bar graphs in Figure 2 (see supplemental information for the actual numbers of percentage of cell viability, Additional file 1: Table S2).

From Figure 2A, our data indicated that 50 and $150 \mu \mathrm{g} / \mathrm{mL}$ of hot water extracts from the bulbs of $C$. longa could specifically affect cell viability of HepG2. However, Kim et al. (2009) reported that $500 \mu \mathrm{g} / \mathrm{mL}$ of C. longa hot water extract had no cytotoxicity effect on the same kind of cell. This variation of concentration may be due to the different conditions used for the MTT assay. Interestingly, crude extract of $C$. longa by 


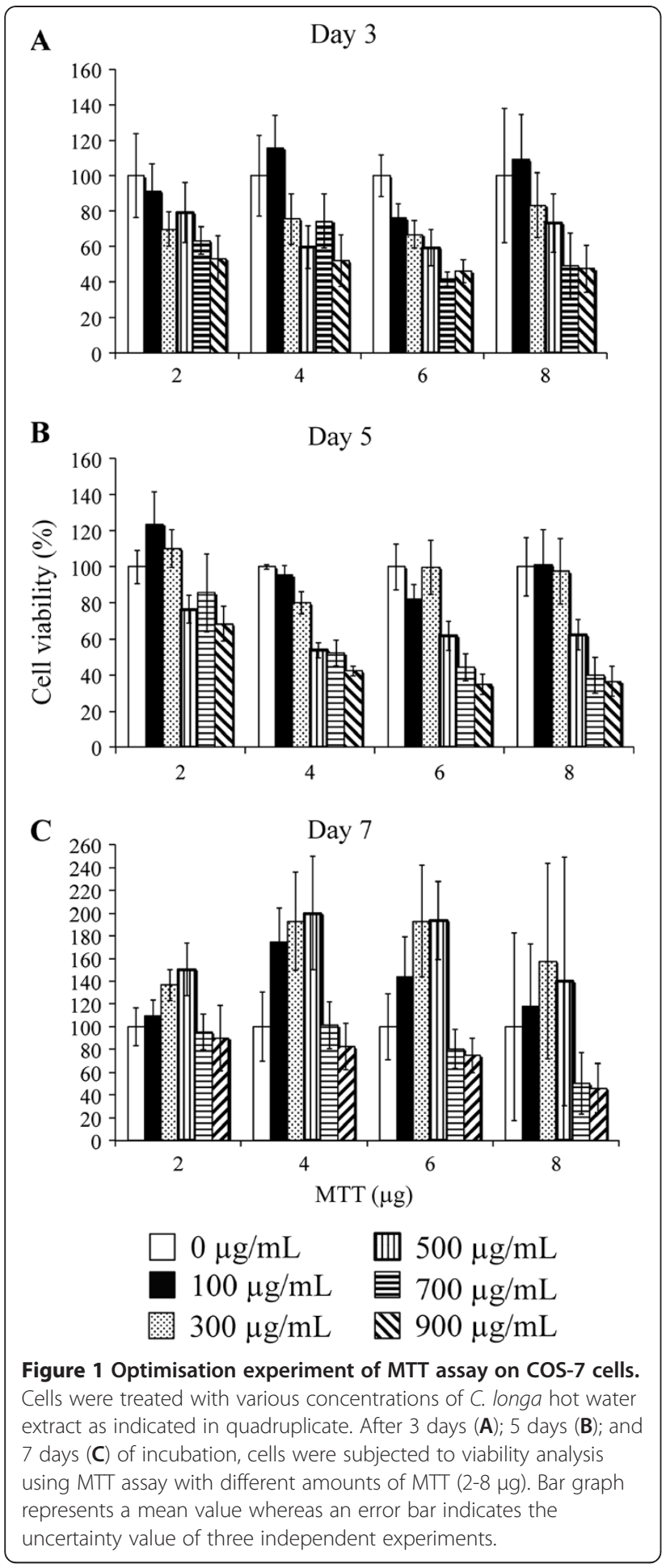

Tris- $\mathrm{HCl}$ buffer did not inhibit cell viability on HepG2 cells (Figure 2B). This result may suggest that proteins are not involved in the inhibitory effects. Nonetheless, higher amount of total protein may be needed to confirm the MTT result of C. longa buffer extract. Curcumin is the product obtained by solvent extraction of $C$. longa and is known to have anti-liver cancer activity [21]. However, our result showed that cytotoxicity effect of $80 \%$ hydro-alcoholic C. longa crude extract on HepG2 cells had no significant differences from the COS-7 cells (Figure 2C). Therefore, the higher concentration of $C$. longa $80 \%$ ethanol extraction may be required to have an effect on the cells.

For the buffer extracts, the results indicated that 0.5 $\mu \mathrm{g}$ of total protein extraction from leaves of C. formosum significantly decreased cell viability of the HepG2 cells without affecting cell viability of COS-7 cells (Figure 2B: $\mathrm{p}<0.001)$. A similar observation was found for $2 \mu \mathrm{g}$ of total protein extraction from the leaves of $M$. charantia and the fruits of $M$. oleifera (Figure 2B: $\mathrm{p}<0.01$ and 0.001 respectively). However, higher amounts of protein extracts from the leaves of $C$. formosum seemed to have a greater cytotoxic effect on normal cells than the HepG2 cells. Up to now, there has not been a report on biological active peptides or hepatoprotective proteins from the extraction of $C$. formosum. Therefore, it is very interesting to examine novel peptides or a proteomic profile of $C$. formosum buffer extract. In addition, the crude extract of C. formosum leaves by $80 \%$ ethanol displayed a significant difference of inhibitory effect between the HepG2 and COS-7 cells (Figure 2C: $\mathrm{p}<$ $0.001)$. This effect is likely due to chlorogenic acid, dicaffeoylquinic acid and ferulic acid derivatives that are previously reported to play important roles in the anticancer activity of C. formosum [11]. Notably, crude extracts by $80 \%$ ethanol from the fruits and leaves of $M$. charantia and $M$. oleifera did not significantly inhibit cell viability of HepG2 cells (Figure 2C). Therefore, the MTT results (Figure 2) suggested that the crude extracts of $C$. formosum are shown to have the best cytotoxicity effect against liver cancer cells whereas hydroalcoholic extracts of M. oleifera (fruit and leaf) and M. charantia (fruit and leaf) do not contain compounds that act specifically against the anti-liver cancer activity.

\section{Some crude extracts of edible plants that could} significantly decrease the level of HBV ccCDNA in HepG2 cells

To study the effect of crude extracts on the replication of $\mathrm{HBV}$, the level of $\mathrm{HBV}$ transcription template (ccCDNA) was determined using quantitative real-time PCR. This experiment included C. longa hot water extract as the analytical control and we found that the extract significantly inhibited cccDNA of HBV with $85 \%$ inhibition (data not shown). This result was consistent with the previous report indicating that $C$. longa hot water extract has anti-HBV activity [9]. In addition, almost all the buffer extracts $(0.3 \mu \mathrm{g}$ of total protein $)$ significantly decreased the level of HBV cccDNA in transiently transfected HepG2 cells with the DNA 
A

C. longa (bulb)
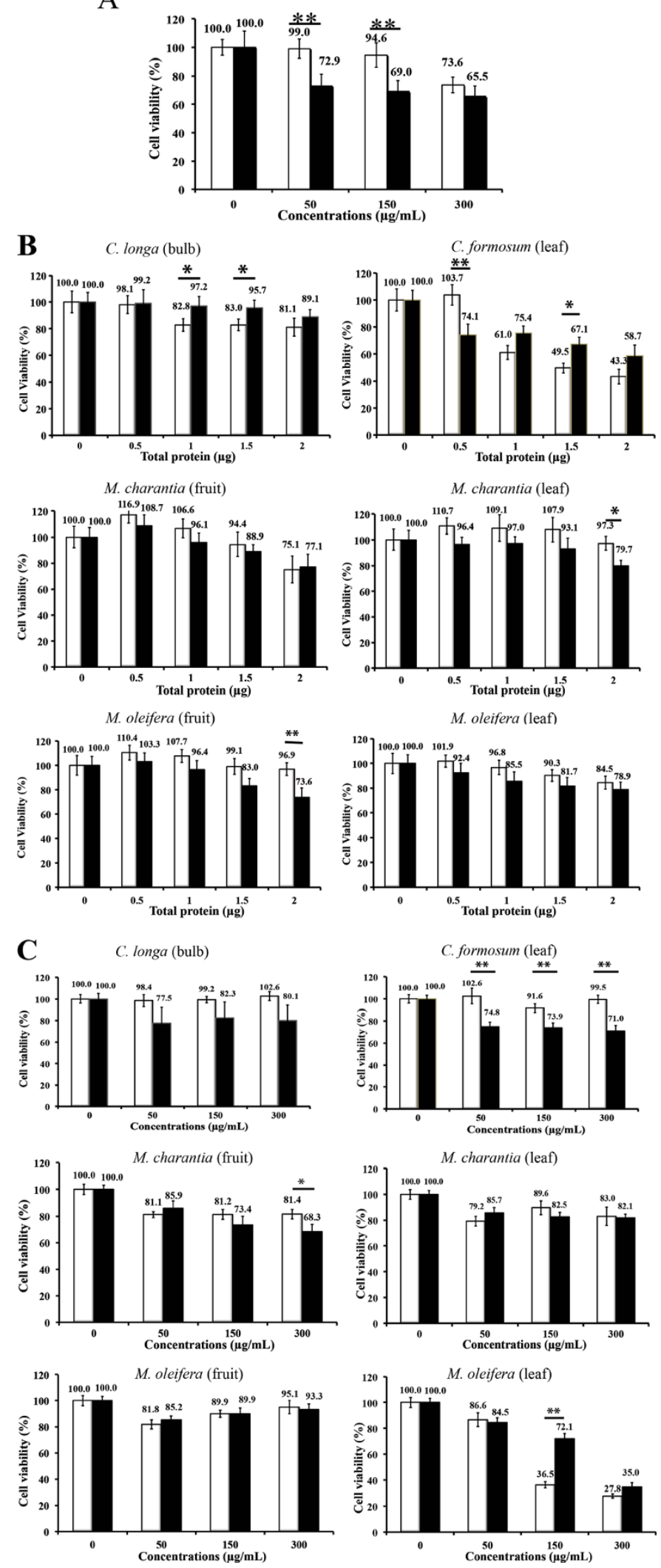

Figure $\mathbf{2}$ (See legend on next page.) 
(See figure on previous page.)

Figure 2 The cytotoxicity effects from plant extracts on COS-7 and HepG2 cells. (A) The effect from hot water extract of C. longa (bulb), (B) The effects from buffer extracts and (C) The effects from $80 \%$ hydroalcoholic extracts. The white bars represent the percentage of cell viability of COS-7 cells whereas the black bars represent the percentage of cell viability of HepG2 cells. Bar graph represents a mean value whereas an error bar indicates the uncertainty value of three independent experiments. "** and "**" indicated significant inhibitory effect when compared with both cell lines at $p<0.01$ and $p<0.001$ (by t-test) respectively.

expression plasmid of HBV genome (Figure 3). The best inhibition from the buffer extractions was observed in $C$. longa (bulb), C. formosum (leaf) and M.oleifera (leaf) with about $80 \%$ inhibition whereas $M$. oleifera (fruit) showed to have a moderate inhibitory effect with about $50 \%$ inhibition. Notably, buffer extracts from the fruits and leaves of $M$. Charantia were found to drastically reduce gene expression of the reference gene (beta-globin) when compared with untreated cells, thus we did not analyse their effects on the level of HBV cccDNA (Figure 3). This is the first report on the anti-HBV activity of crude extracts by the buffer method from C. longa (bulb), C. formosum (leaf) and M.oleifera (leaf). Further experiments will be carried out to investigate any potential anti-HBV compounds from these plant extracts including their mechanism inside the cells.

Furthermore, our results suggest that $30 \mu \mathrm{g} / \mathrm{mL}$ aqueous ethanol extracts of $M$. olifera (fruit) and C. longa (bulb) drastically decreased the level of HBV cccDNA with greater than $85 \%$ inhibition. The $30 \mu \mathrm{g} / \mathrm{mL}$ hydroalcoholic extracts of $C$. formosum (leaf) and $M$. Charantia (leaf) also showed a moderate inhibition of the level of HBV cccDNA with $50 \%$ inhibition. Hence, our results suggested that crude extracts from $80 \%$ ethanol of $C$. longa (bulb), C. formosum (leaf), $M$. olifera (fruit) and M. Charantia (leaf) contain compounds that could inhibit HBV replication. On the other hand, $30 \mu \mathrm{g} / \mathrm{mL}$ ethanol extracts of $M$. Charantia (fruit) and $M$. oleifera (leaf) had no effect on the level of HBV cccDNA (Figure 3). Therefore, the M. oleifera (leaf) ethanol extracts have antiviral activities against herpes simplex virus type 1 (HSV-1) [15] and Sindbis virus [22], but not HBV.

\section{Conclusion}

In this study, we provided the first report on the cytotoxicity effect against liver cancer cell and anti-HBV activity from crude extracts of $C$. formosum (leaf) by using $80 \%$ ethanol and Tris- $\mathrm{HCl}$ solvents. A mild cytotoxicity effect on HepG2 cells was also observed with the buffer extracts of $M$. charatia (leaf) and M. oleifera (fruit), and the hydroalcoholic extracts of these plants were also able to inhibit HBV cccDNA. These results are promising and are to be followed with further analysis of isolated phytochemicals and proteins from these extracts including the identification of the

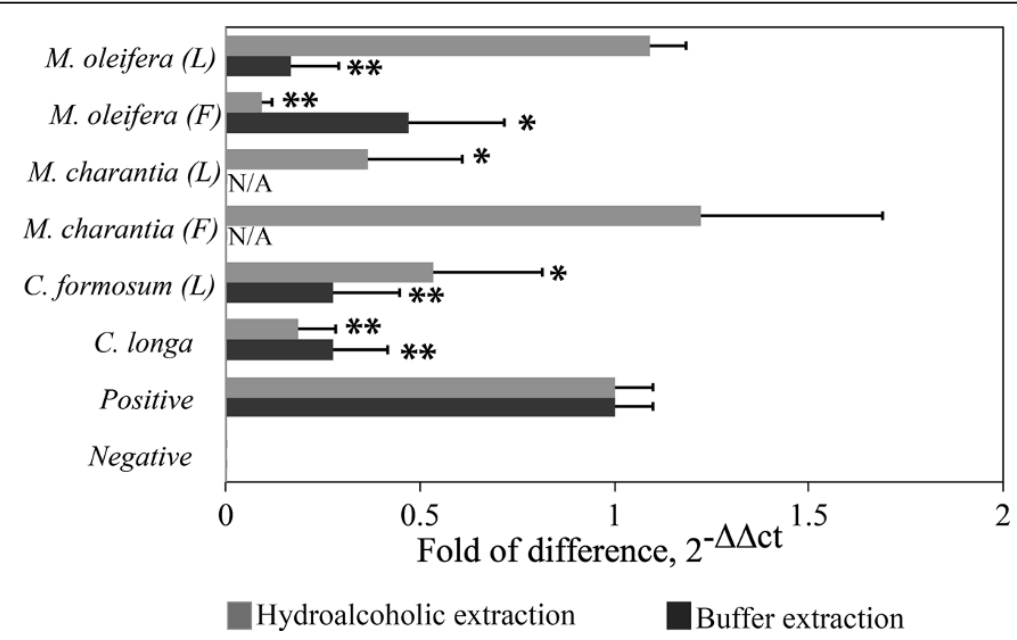

Figure 3 Effects of crude extracts on the level of cccDNA in transiently transfected HepG2 cells with the DNA expression plasmid of HBV genome. HepG2 cells were treated with either $30 \mu \mathrm{g} / \mathrm{mL}$ of hydroalcoholic extracts or $0.3 \mu \mathrm{g}$ of buffer extracts and were transfected with $1 \mu \mathrm{g}$ of the DNA expression plasmid of HBV genome using Lipofectamine ${ }^{\mathrm{TM}} 2000$ in triplicate. After 5 days of incubation, the total DNA of each well was extracted and subjected for quantitative real-time analysis. Bar graph represents a mean value whereas an error bar indicates the uncertainty value of three independent experiments. "**" and "***" indicate significant inhibitory effect when compared with the positive cccDNA at $p<0.01$ and $p<0.001$ (by t- test) respectively. "F" is for fruit and "L" is for leaf. 
molecular processes that may be targeted by components in these plant extracts.

\section{Additional file}

Additional file 1: Table S1. The extract yield (\%, w/w) of hydroalcoholic extracts and total protein of buffer extracts. Table S2. Effects of crude extracts on the cell viability of COS-7 and HepG2 cells.

\section{Competing interests}

The authors declare that they have no competing interests.

\section{Authors' contributions}

WW carried out the sample preparation and extraction, some MTT assays and real-time PCR. SP designed and was involved in the analysis of real-time PCR experiments. Jl carried out protein dialysis and total protein assay. NTP performed some MTT assays, conceived the idea, designed and coordinated the study and prepared the manuscript. All authors read and approved the final manuscript.

\section{Acknowledgements}

This work and WW were supported by the TRF-MAG Window II Grant (Grant number: MRG WII525S101). NTP is funded by a KURDI Grant (Por Tor Dor 90.55), a Research Grant for New Scholar (co-funded by TRF and CHE: Grant Number MRG5380104) and a ScRF from Faculty of Science, Kasetsart University (ScRF-E13/2553). We would like to thank the Centre of Excellence Clinical Virology and Molecular Biology Research, Chulalongkorn University for providing the real-time PCR machine and Dr. Karl Bailey for proofreading the manuscript.

\section{Author details}

'Department of Biochemistry, Faculty of Science, Kasetsart University, Bangkok, Thailand. 'Department of Biochemistry, Faculty of Medicine, Chulalongkorn University, Bangkok, Thailand.

Received: 28 June 2012 Accepted: 24 November 2012

Published: 6 December 2012

\section{References}

1. Tillmann HL: Antiviral therapy and resistance with hepatitis B virus infection. World J Gastroenterol 2007, 13:125-140.

2. Surh YJ: Cancer chemoprevention with dietary phytochemicals. Nat Rev Cancer 2003, 3:768-780.

3. Arakawa T, Yamasaki H, lkeda K, Ejima D, Naito T, Koyama AH: Antiviral and virucidal activities of natural products. Curr Med Chem 2009, $16: 2485-2497$

4. Neergheen VS, Bahorun T, Taylor EW, Jen LS, Aruoma Ol: Targeting specific cell signaling transduction pathways by dietary and medicinal phytochemicals in cancer chemoprevention. Toxicology 2010, 278:229-241.

5. Chattopadhyay D, Sarkar MC, Chatterjee T, Sharma Dey R, Bag P, Chakraborti S, Khan MT: Recent advancements for the evaluation of anti-viral activities of natural products. N Biotechnol 2009, 25:347-368.

6. Fransworth NR, Bunyapraphatsara N: Thai medicinal plants recommended for primary health care system. In Medicinal plants information center, faculty of pharmacy. Edited by Fransworth NR, Bunyapraphatsara N. Bangkok: Mahidol University; 1992:130-138.

7. Itharat A, Ooraikul B: Research on Thai medicinal plants for cancer treatment. In Advances in Medicinal Plant Research. Edited by Acharya SN, Thomas JE. Keraka: Research Signpost; 2007:287-317.

8. Buhrmann C, Mobasheri A, Busch F, Aldinger C, Stahlmann R, Montaseri A, Shakibaei M: Curcumin modulates NF-\{kappa\}B-mediated inflammation in human tenocytes in vitro: role of the phosphatidylinositol 3-kinase-Akt pathway. J Biol Chem 2011, 286:28556-28566.

9. Kim HJ, Yoo HS, Kim JC, Park CS, Choi MS, Kim M, Choi H, Min JS, Kim YS, Yoon SW, Ahn JK: Antiviral effect of Curcuma longa Linn extract against hepatitis B virus replication. J Ethnopharmacol 2009, 124:189-196.
10. Kim K, Kim KH, Kim HY, Cho HK, Sakamoto N, Cheong J: Curcumin inhibits hepatitis $C$ virus replication via suppressing the Akt-SREBP-1 pathway. FEBS Lett 2010, 584:707-712.

11. Maisuthisakul P, Pongsawatmanit R, Gordon MH: Antioxidant properties of Teaw (Cratoxylum formosum Dyer) extract in soybean oil and emulsions. J Agr Food Chem 2006, 54:2719-2725.

12. Grosvenor PW, Supriono A, Gray DO: Medicinal plants from Riau province, Sumatra, Indonesia. Part 2: Antibacterial and antifungal activity. J Ethnopharmacol 1995, 45:97-111.

13. Ray RB, Raychoudhuri A, Steele R, Nerurkar P: Bitter melon (Momordica charantia) extract inhibits breast cancer cell proliferation by modulating cell cycle regulatory genes and promotes apoptosis. Cancer Res 2010, 70:1925-1931.

14. Zheng YT, Ben KL, Jin SW: Alpha-momorcharin inhibits HIV-1 replication in acutely but not chronically infected T-lymphocytes. Zhongguo Yao Li Xue Bao 1999, 20:239-243.

15. Lipipun V, Kurokawa M, Suttisri R, Taweechotipatr P, Pramyothin P, Hattori $M$, Shiraki K: Efficacy of Thai medicinal plant extracts against herpes simplex virus type 1 infection in vitro and in vivo. Antivir Res 2003, 60:175-180

16. Murakami A, Kitazono Y, Jiwajinda S, Koshimizu K, Ohigashi H: Niaziminin, a thiocarbamate from the leaves of Moringa oleifera, holds a strict structural requirement for inhibition of tumor-promoter-induced Epstein-Barr virus activation. Planta Med 1998, 64:319-323.

17. Wu HL, Chen PJ, Lin MH, Chen DS: Temporal aspects of major viral transcript expression in Hep G2 cells transfected with cloned hepatitis B virus DNA: with emphasis on the $X$ transcript. Virology 1991, 185:644-651.

18. Rollino C, Borsa S, Bellone G, Piccoli G, Emanuelli G: False positive results with MTT assay. J Immunol Methods 1995, 185:141-143.

19. He ML, Wu J, Chen Y, Lin MC, Lau GK, Kung HF: A new and sensitive method for the quantification of HBV cccDNA by real-time PCR. Biochem Biophys Res Commun 2002, 295:1102-1107.

20. Moore DS, McCabe GP: Introduction to the practice of statistics. New York: Freeman WH and Co Publisher; 2000:112-129.

21. Goel A, Aggarwal BB: Curcumin, the golden spice from Indian saffron, is a chemosensitizer and radiosensitizer for tumors and chemoprotector and radioprotector for normal organs. Nutr Cancer 2010, 62:919-930.

22. Beloin N, Gbeassor M, Akpagana K, Hudson J, de Soussa K, Koumaglo K, Arnason JT: Ethnomedicinal uses of Momordica charantia (Cucurbitaceae) in Togo and relation to its phytochemistry and biological activity. J Ethnopharmacol 2005, 96:49-55.

doi:10.1186/1472-6882-12-246

Cite this article as: Waiyaput et al:: Inhibitory effects of crude extracts from some edible Thai plants against replication of hepatitis B virus and human liver cancer cells. BMC Complementary and Alternative Medicine 2012 12:246.

\section{Submit your next manuscript to BioMed Central and take full advantage of:}

- Convenient online submission

- Thorough peer review

- No space constraints or color figure charges

- Immediate publication on acceptance

- Inclusion in PubMed, CAS, Scopus and Google Scholar

- Research which is freely available for redistribution
Biomed Central 